\title{
ISOTERMI SORPSI AIR IKAN KAYU (Katsuo-Bushi) YANG DIBUAT DENGAN KONSENTRASI ASAP CAIR DAN LAMA PERENDAMAN YANG BERBEDA
}

\author{
Grace Tnuwo ${ }^{1}$, Siegfried Berhimpon ${ }^{2}$, Nurmelita Taher ${ }^{2}$, \\ Grace Sanger $^{2}$, Eunike Mongi ${ }^{2}$, Feny Mentang ${ }^{2}$, Verly Dotulong ${ }^{2}$ \\ ${ }^{1}$ Mahasiswa pada Program Studi Teknologi Hasil Perikanan FPIK UNSRAT Manado. \\ ${ }^{2}$ Staf Pengajar pada Program Studi Teknologi Hasil Perikanan FPIK UNSRAT Manado.
}

\begin{abstract}
Wooden fish, better known as Katsuo-bushi, which is done in stages. Wood fish has a weight around $20-30 \%$ of raw materials with a moisture content of $15-17 \%$ because it experiences fumigation/drying. The problem for products that are smoked long (Hard Smoking) is the content of carcinogens which also settles on fish is quite high, therefore fumigation technology with liquid smoke become an alternative in wood fish processing to minimize the content of carcinogens. The purpose of this study is to determine the isotherm of water sorption in wood fish (Katsuo-bushi) which is made with different concentrations of liquid smoke and soaking time. Method used in this study the method of analysis, water content, ph analysis method and Isothermic sorption (ISA) analysis method.
\end{abstract}

Keyword: Isotherm sorpsi water (ISA) Katsuo-bushi, liquid smoke.

Ikan kayu atau lebih dikenal dengan Katsuo-bushi termasuk dalam produk olahan pengasapan, yang dilakukan secara bertahap. Ikan kayu memiliki berat sekitar 20-30\% dari bahan baku, dengan kadar air $15-17 \%$ karena mengalami proses pengasapan/pengeringan. Masalah bagi produk yang diasapi lama (Hard Smoking) adalah kandungan senyawa karsinogen yang ikut mengendap pada ikan cukup tinggi. Karena itu teknologi pengasapan dengan asap cair menjadi alternatif dalam pengolahan ikan kayu untuk meminimalisir kandungan senyawa karsinogen. Pengolahan ikan kayu menggunakan asap cair memiliki beberapa kelebihan yaitu rendah kandungan PAH $(<25 \mathrm{ppb})$, ramah lingkungan karena tidak ada polusi udara, dan hemat bahan bakar kayu, serta waktu pengolahan singkat. Parameter yang digunakan dalam penelitian ini adalah metode analisa kadar air (AOAC, 2005) metode analisa pH (AOAC, 2005) dan metode analisa isotermi sorpsi air. Hasil penelitian ini menunjukkan bahwa ISA ikan kayu asap cair mendapatkan model kurva ISA tipe 1 dengan persamaan nilai Henderson 4,915 yang sangat tepat sedangkan untuk persamaan Hasley 6,522 yang agak tepat. Persamaan Oswin, Caurie, dan Chen Clayton memiliki model persamaan yang tidak tepat karena lebih dari angka 10. Hasil yang didapatkan berbeda dari penelitian sebelumnya serta mempunyai perbedaan konsentrasi asap cair dan lama perendaman yang berbeda, karena penelitian sebelumnya mendapatkan nilai MRD Oswin 16,44 yang sangat tepat.

Kata kunci: isotermi sorpsi air (ISA), ikan kayu, asap cair.

\section{PENDAHULUAN}

Ikan kayu atau lebih dikenal dengan Katsuo-bushi termasuk dalam produk olahan pengasapan, yang dilakukan secara bertahap. Ikan kayu memiliki berat sekitar 20-30\% dari bahan baku, dengan kadar air 15-17\% karena mengalami proses pengasapan/pengeringan. Masalah bagi produk yang diasapi lama (Hard Smoking) adalah kandungan senyawa karsinogen yang ikut mengendap pada ikan cukup tinggi. Karena itu teknologi pengasapan dengan asap cair menjadi alternatif dalam pengolahan ikan kayu untuk meminimalisir kandungan senyawa karsinogen

Menurut Sutin (2008), asap cair dapat digunakan sebagai pengawet makanan karena mengandung senyawa-senyawa antibakteri. Asap cair banyak digunakan dalam pengolahan industri makanan salah satunya dapat digunakan dalam pengolahan ikan kayu asap cair. Pengolahan ikan kayu menggunakan asap cair memiliki beberapa kelebihan yaitu rendah kandungan PAH (<25 ppb), ramah lingkungan karena tidak ada polusi udara, dan hemat bahan bakar kayu, serta waktu pengolahan singkat. (Berhimpon et.al.., 2017).

Isotermi soprsi air (ISA) adalah kurva yang menghubungkan data kadar seimbang dengan aktivitas air suatu bahan pada suhu yang sama (Adawiyah dan Soekarto, 2010). Selain mengindikasikan nilai aktivitas air pada komposisinya, kurva ini juga memiliki 
hubungan yang erat dengan stabilitas bahan pangan pada berbagai kondisi penyimpanan dan kebutuhan proses pengemasan produk pangan untuk menjaga kestabilan masa simpan, pada suatu bahan pangan. Secara umum sifat-sifat hidratasi ini dapat digambarkan dalam kurva isotermi, yaitu kurva yang menunjukkan hubungan antara kadar air keseimbangan bahan pangan dengan kelembaban relatif seimbang ruang tempat penyimpanan (ERH) atau aktivitas air (aw) pada suhu tertentu, (Syarief dan Halid, 1993 dalam Ahmad et.al., 2014), pada umumnya kurva isotermi bahan pangan berbentuk sigmoid (menyerupai huruf $\mathrm{S}$ ). Selain daya awet dari produk ikan kayu asap cair maka perlu diketahui jumlah stabilitas produk tersebut selama disimpan dengan kondisi pada $\mathrm{RH}$ yang berbeda.

Adapun tujuan penelitian ini adalah untuk mengetahui isotermi sorpsi air ikan kayu (Katsuo-bushi) yang dibuat dengan konsentrasi asap cair dan lama perendaman yang berbeda.

\section{METODOLOGI PENELITIAN}

Penelitian ini dilakukan di Laboratorium Teknologi Penanganan dan Pengolahan Hasil Perikanan dan Laboratorium Pengendalian Mutu Hasil Perikanan Fakultas Perikanan dan Ilmu Kelautan Universitas Sam Ratulangi.

\section{Bahan dan Alat Penelitian Bahan}

Ikan cakalang (Katsuwonus pelamis L.) dengan ukuran 1-1,2 $\mathrm{kg}$, akuades, tempurung kelapa, larutan buffer $\mathrm{pH} 4$ dan $\mathrm{pH} 7, \mathrm{pH}$ meter (merk Adwa tipe AD 1000), toluene, garam jenuh $\mathrm{NaOH}, \mathrm{LiCl}, \mathrm{MgCl}, \mathrm{K}_{2} \mathrm{CO}_{3}, \mathrm{Mg}\left(\mathrm{NO}_{3}\right)$, $\mathrm{NaNO}_{2}, \mathrm{NaCl}, \mathrm{KCl}$, dan $\mathrm{K}_{2} \mathrm{SO}_{4}$.

\section{Alat}

Pisau, talenan, timbangan, gelas ukur, wadah untuk ikan, kompor, lemari pengering (cabinet dryer), plastik ziplock, timbangan analitik (merk 22 Adam ) mortal dan pastle, beker glass, desikator, cawan porselin, oven, penjepit.

\section{Perlakuan}

A. Kosentrasi asap cair $(2,4,6$ dan $8 \%)$;

B. Lama perendaman dalam asap cair $(30,60$, 90 dan 120 menit).

\section{Analisa Data ISA}

Analisa ISA ikan kayu asap cair menggunakan lima model persamaan yaitu Hasley, Chen-Clayton, Henderson, Caurie dan Oswin. Jika nilai MRD (Mean Relative Determination) kurang dari angka 5, maka model ISA tersebut dapat menggambarkan keadaan sebenarnya atau sangat tepat menggambarkan keadaan yang sebenarnya. Jika nilai MRD antara angka 5 dan 10, maka model tersebut agak tepat menggambarkan keadaan sebenarnya. Jika nilai MRD lebih dari angka 10, maka model persamaan tersebut tidak tepat menggambarkan kondisi yang sebenarnya.

\section{Tata Laksana Penelitian}

Pembuatan ikan kayu asap cair adalah sebagai berikut:

- Ikan cakalang kurang lebih sebanyak $\pm 10 \mathrm{~kg}$ dengan ukuran (1-1,2 kg) dicuci kemudian dilakukan penyiangan dimana insang dan isi perut dikeluarkan.

- Kemudian ikan yang sudah disiangi, dicuci bersih lalu direbus selama 90 menit dengan temperatur perebusan $90-100^{\circ} \mathrm{C}$ (temperatur diukur dengan menggunakan thermocouple) setelah perebusan, ikan didinginkan kurang lebih selama 30 menit lalu ikan dibagi menjadi empat bagian (fillet).

- Setiap filet dilakukan pembersihan kulit dan pencabutan tulang, kemudian direndam dalam larutan asap cair dengan konsentrasi 2, 4, 6 dan $8 \%$ selama 30, 60, 90 dan 120 menit.

- Selanjutnya, ikan dikeringkan dalam oven pengering selama 2 jam pada temperatur $85^{\circ} \mathrm{C}$.

- Setelah pengeringan 2 jam pertama ikan dikeluarkan dan didiamkan selama 4 jam, dan kemudian direndam kembali dalam larutan asap cair dengan konsentrasi dan lama perendaman yang sama, kemudian dikeringkan kembali pada temperatur $65^{\circ} \mathrm{C}$ selama 2 jam.

- Perendaman pengeringan dilakukan kurang lebih sebanyak 7 kali hingga memperoleh kadar air yang diinginkan yaitu 15-17\%.

- Produk ikan kayu yang sudah jadi, kemudian dianalisa di laboratorium dengan melakukan uji kadar air, pH, dan ISA.

\section{Parameter Pengamatan \\ Prosedur Analisis Kadar Air (AOAC, 2005)}

Analisis kadar air dilakukan dengan menggunakan metode oven. Prinsipnya adalah 
menguapkan molekul air $\left(\mathrm{H}_{2} \mathrm{O}\right)$ bebas yang ada dalam sampel. Kemudian sampel ditimbang sampai didapat bobot konstan yang diasumsikan semua air yang terkandung dalam sampel sudah diuapkan.

\section{Prosedur Analisa pH (AOAC, 2005)}

Dalam penelitian ini analisa kadar $\mathrm{pH}$ ikan kayu asap cair menggunakan alat $\mathrm{pH}$ meter dengan prosedur analisa $\mathrm{pH}$ (AOAC, 2005). Sampel ditimbang sebanyak 5 gram kemudian ditambahkan akuades $10 \mathrm{ml}$ dan dihomogenkan selama satu menit. Sampel yang sudah homogen dipindahkan ke dalam beker glass $50 \mathrm{ml}$, lalu diukur pHnya menggunakan alat $\mathrm{pH}$ meter.

Prosedur Analisa Isotermi Sorpsi Air (ISA), (Berhimpon, 1990)

- Desikator diisi larutan garam jenuh yang mempunyai Relative Humidity $(\mathrm{RH})$ antara 997\% sampai setengah bagian dasarnya. Pada penelitian ini, akan diberikan larutan jenuh dari beberapa garam yang memberikan kisaran RH dari 6,9\% sampai dengan $97 \%$ yaitu: $\mathrm{NaOH}(\mathrm{RH} 6,9 \%) ; \mathrm{LiCl}(11 \%) ; \mathrm{MgCl}_{2}$ (32\%); $\mathrm{K}_{2} \mathrm{CO}_{3} \quad$ (44\%); $\mathrm{Mg}\left(\mathrm{NO}_{3}\right)_{2} \quad(53 \%)$; $\mathrm{NaNO}_{2}(64 \%) ; \mathrm{NaCl}(76 \%) ; \mathrm{KCl}(87 \%)$ dan $\mathrm{K}_{2} \mathrm{SO}_{4}(97 \%)$. Untuk menjamin kejenuhannya larutan tersebut, masing-masing garam tersebut diberi secara berlebihan, kemudian ditutup rapat dan simpan sampai waktunya akan digunakan kurang lebih 10-14 hari.

- Sampel yang akan dianalisa dipotong kecil sekitar 2 gram dan masukkan ke dalam cawan porselen. Sampel tersebut kemudian diberi kode kemudian dimasukkan dalam desikator yang berisi larutan jenuh garam yang mempunyai RH tertentu. Setiap perlakuan dibuat ulangan sebanyak dua kali.

- Untuk mencegah pertumbuhan mikroba maka, diletakkan botol kecil yang berisi $5 \mathrm{ml}$ toluene pada setiap desikator yang mempunyai RH 60\% atau lebih.

- Setelah tujuh hari larutan diperiksa untuk memperoleh kepastian akan kejenuhannya, lalu sampel ditimbang untuk mengetahui beratnya. Timbang sampel secara berulangulang sampai mencapai berat konstan.

- Setelah keseimbangannya diperoleh, masingmasing sampel dianalisa kadar airnya dan kadar air yang diperoleh adalah kadar air keseimbangan.

\section{HASIL DAN PEMBAHASAN}

\section{Analisa Kadar Air Ikan Kayu Asap Cair}

Nilai rata-rata kadar air pada masingmasing perlakuan dengan konsentrasi asap cair dan lama perendaman yang berbeda dapat dilihat pada Gambar 1.

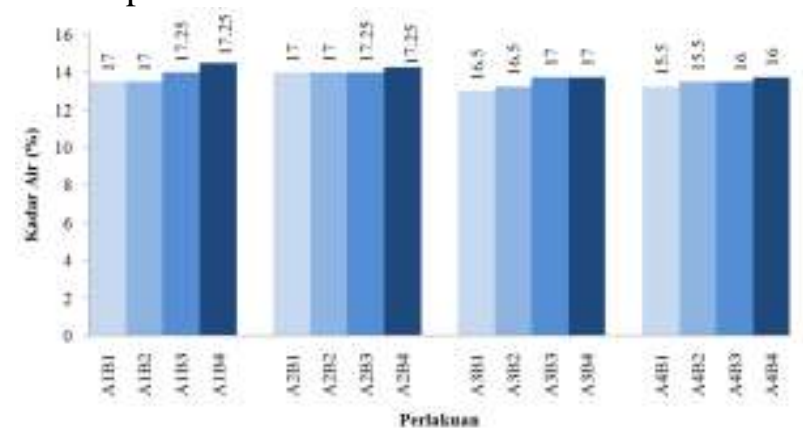

Gambar 1. Histogram kadar air ikan kayu asap cair. Ket.:

$\mathrm{A} 1=$ Konsentrasi $2 \% \quad \mathrm{~B} 1=$ Lama perendaman 30 menit $\mathrm{A} 2=$ Konsentrasi $4 \% \quad \mathrm{~B} 2=$ Lama perendaman 60 menit A3 $=$ Konsentrasi $6 \% \quad$ B3 $=$ Lama perendaman 90 menit A4 $=$ Konsentrasi 8\% $\quad$ B4 = Lama perendaman 120 menit

Berdasarkan histrogram pada Gambar 1 ikan kayu asap cair yang menunjukkan nilai rata-rata kadar air tertinggi $17,25 \%$, sedangkan nilai kadar air terendah kadar air 15,5\%.

Dari hasil tersebut dapat dilihat bahwa, lama perendaman memberikan pengaruh terhadap kadar air ikan kayu asap cair. Hal ini sesuai dengan penelitian sebelumnya, dimana lama perendaman mempengaruhi kadar air dari produk ikan kayu asap cair Katiandagho (2016).

Agus, et.al., (2014) menyatakan bahwa kadar air merupakan parameter yang penting untuk menentukan kualitas ikan kayu yang dihasilkan. Kadar air yang terkandung di dalam ikan kayu dapat mempengaruhi daya simpan, karena kadar air merupakan media mikroba untuk berkembang biak. Seperti yang diketahui bahwa meningkat atau menurunnya kadar air bahan pangan merupakan dampak dari kecenderungan adanya perbedaan kelembaban udara sekitarnya, dengan kata lain kandungan kadar air bahan pangan akan berubah-ubah sesuai dengan lingkungannya.

\section{Analisa pH Ikan Kayu Asap Cair}

Nilai rata-rata $\mathrm{pH}$ pada masing-masing perlakuan dengan konsentrasi asap cair dan lama perendaman yang berbeda dapat dilihat pada Gambar 2. 


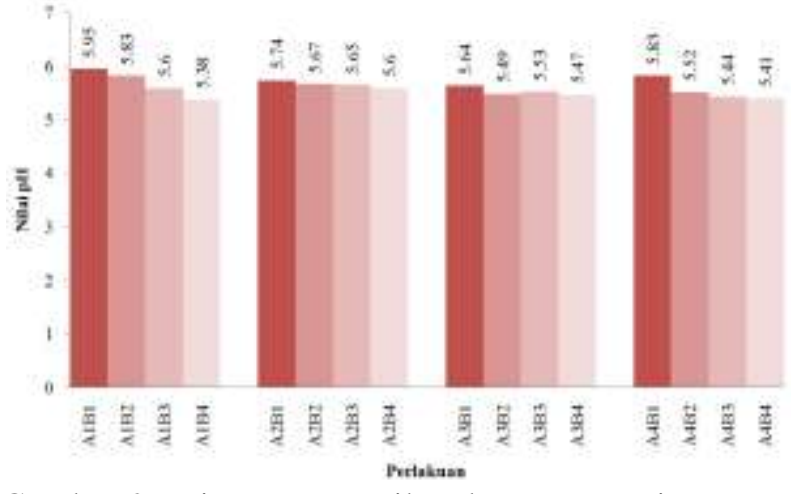

Gambar 2. Histogram pH ikan kayu asap cair. Ket.:

$$
\begin{array}{ll}
\text { A1 }=\text { Konsentrasi 2\% } & \text { B1 }=\text { Lama perendaman } 30 \text { menit } \\
\text { A2 }=\text { Konsentrasi 4\% } & \text { B2 }=\text { Lama perendaman 60 menit } \\
\text { A3 }=\text { Konsentrasi 6\% } & \text { B3 = Lama perendaman 90 menit } \\
\text { A4 }=\text { Konsentrasi 8\% } & \text { B4 = Lama perendaman } 120 \text { menit }
\end{array}
$$

Berdasarkan nilai rata-rata dari konsentrasi asap cair dan lama perendaman yang berbeda, $\mathrm{pH}$ ikan kayu asap cair yang tertinggi $\mathrm{pH} 5,95$ sedangkan nilai $\mathrm{pH}$ terendah 5,38. Dari hasil tersebut dapat dilihat bahwa lama perendaman memberikan pengaruh kecil terhadap $\mathrm{pH}$ dari ikan kayu asap cair.

Menurut Berhimpon (1974), bahwa tinggi rendahnya nilai $\mathrm{pH}$ dipengaruhi oleh lamanya pengasapan, dimana pada pengasapan yang berlangsung lebih lama, maka unsur asap yang terserap dan melekat pada produk lebih banyak, demikian juga senyawa asam yang terserap juga meningkat. Pengawetan dengan asap cair memiliki $\mathrm{pH}$ bahan pangan sekitar 6,0 dimana pada $\mathrm{pH}$ netral atau bahkan $\mathrm{pH}$ yang lebih rendah atau bahan pangan yang bersifat asam diketahui bahwa pertumbuhan mikroorganisme dapat terhambat, (Wisniewski dan Manrer, 1979 dalam Pelokang, 2010).

\section{Analisa Isotermi Sorpsi Air (ISA) Ikan Kayu Asap Cair}

Analisa isotermi sorpsi air pada ikan kayu asap cair menggunakan lima model persamaan yaitu Hasley, Chen-Clayton, Henderson, Caurie dan Oswin.

Tabel 1. Nilai MRD Model Persamaan (ISA) Ikan Kayu Asap Cair.

\begin{tabular}{lr}
\hline Model Persamaan & Nilai MRD \\
\hline Hasley & $\mathbf{6 , 5 2 2}$ \\
Chen Clayton & 233,550 \\
Henderson & $\mathbf{4 , 9 1 5}$ \\
Caurie & 28,626 \\
Oswin & 21,750 \\
\hline
\end{tabular}

Nilai MRD pada tabel di atas menunjukan bahwa model persamaan yang tepat $<5$ menggambarkan keadaan yang sebenarnya. Jika nilai MRD antara 5 dan 10 maka model tersebut agak tepat, sedangkan nilai MRD lebih dari angka 10 maka model persamaan tersebut tidak tepat. Berdasarkan ke lima model persamaan tersebut persamaan Henderson dengan nilai MRD 4,915 yaitu lebih kecil dan sangat tepat sedangkan hasil persamaan yang lain menunjukan persamaan Hasley dengan nilai MRD 6,522 yang agak tepat, untuk persamaan Oswin, Caurie dan Chen Clayton memiliki model persamaan yang tidak tepat. Untuk model persamaan kurva dari ikan kayu asap cair untuk analisa isotermi sorpsi air dapat dilihat pada Gambar 3.
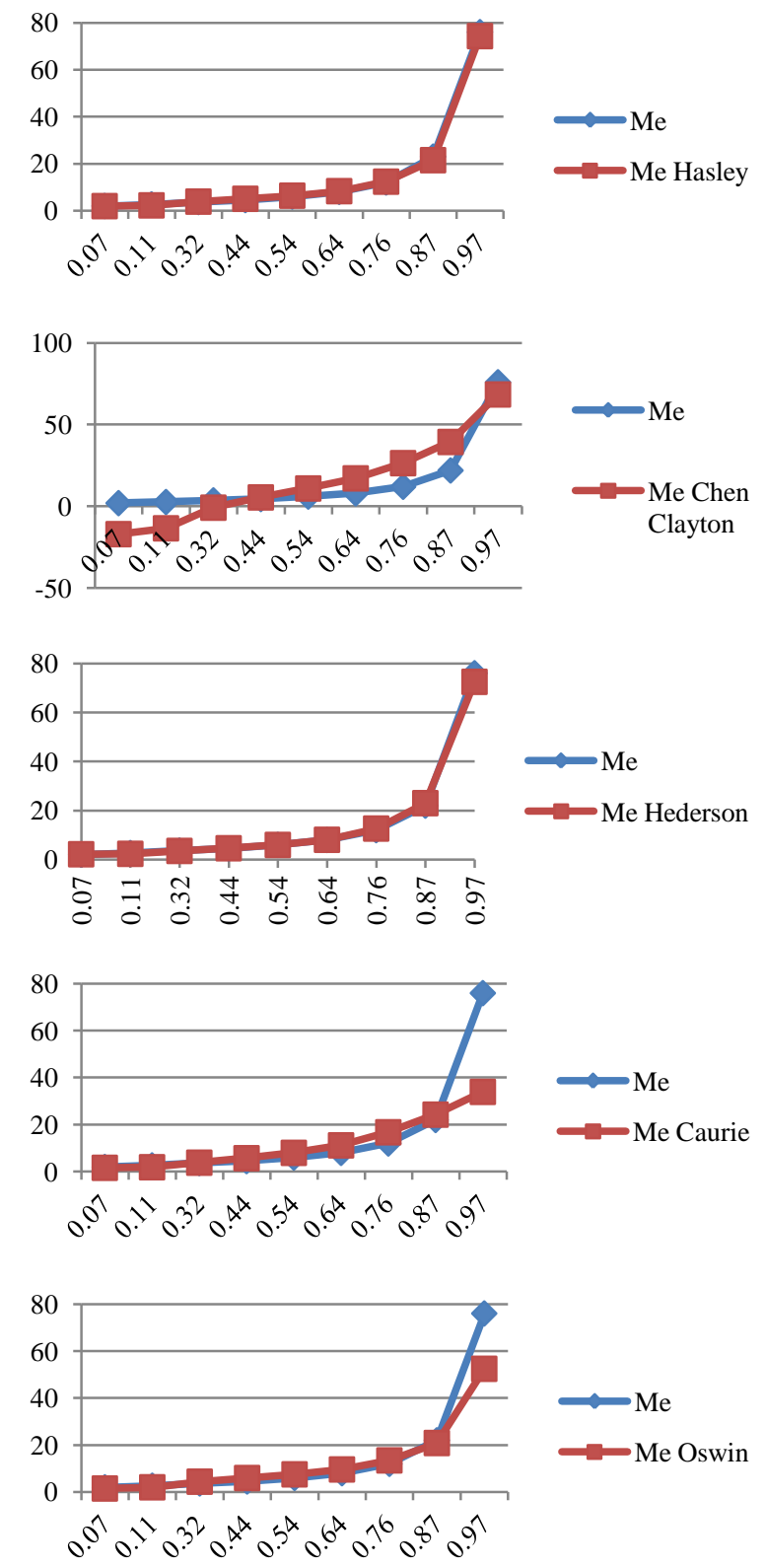

Gambar 3. Model persamaan isotermi sorpsi air ikan kayu asap cair merupakan contoh dari ke lima model persamaan nilai MRD 


\section{KESIMPULAN}

Isotermi Sorpsi air (ISA) ikan kayu asap cair menunjukkan model persamaan kurva ISA tipe 1, dan memiliki model persamaan nilai MRD yang berbeda dari penelitian Katiandagho (2016). Kurva ISA penelitian ini memiliki nilai MRD model persamaan Henderson 4,915 yang sangat tepat dan persamaan Hasley 6,522 yang agak tepat sedangkan untuk model persamaan Oswin, Caurie, dan Chen Clayton memiliki model persamaan yang tidak tepat karena lebih dari angka 10.

Pada RH $>76 \%$ ikan kayu asap cair mengalami peningkatan atau penyerapan air sehingga pada $\mathrm{RH}$ tersebut ikan kayu asap cair perlu kemasan yang baik.

\section{DAFTAR PUSTAKA}

[AOAC] Association of Official Analytical and Chemistry., 2005., Official Methods of Analysis.

Agus. T.S.W., F. Swastawati, da A.P. Anggo. 2014. Kualitas Ikan PAri (Dasyatis sp) Asap Yang Diolah Dengan Ketinggian Tungku Dan Suhu Yang Berbeda. Jurnal Pengolahan dan Bioteknologi Hasil Perikanan, vol 3. No.1 hal 147-156.

Atmaja Adi Kusuma., 2009 Aplikasi Asap Cair Redestilasi Pada Karakteristik Kamaboko Ikan Tongkol (Euthynnus affinis) Ditinjau Dari Tingkat Keawetan dan Kesukaan Konsumen., Skripsi., Fakultas Pertanian Universitas Sebelas Maret., pdf., 8/30/2016/10:41 am.,

Ayudiarti Lestari Diah dan Sari Nurbaya Rodiah., 2010., Asap Cair dan Aplikasinya Pada Produk Perikanan., Squalen Vol. 5 No. 3., Balai Besar Riset Pengolahan Produk dan Bioteknologi Kelautan dan Perikanan; 5/7/2016/12:28pm.,http://www.bbp4b.litbang.kkp.go.i $\mathrm{d} /$ squalenbulletin/index.php/squalen/article/download/ $53 / 33$.

Berhimpon S, Dian HA, Montolalu RI. 2003. Processing And The Prospect Of Katsuobushi (Ikan Kayu) Of North Sulawesi, journal Review. 1-

Berhimpon S., 1974., Pengaruh Bahan Pengawet Kimia dan Lama Penyimpanan Terhadap Mutu Ikan Mas (Caprynus carpio) Asap Yang Disimpan Pada Temperatur Kamar., Thesis., Fakultas Perikanan., Universitas Sam Ratulang-Afiliasi Institut Pertanian Bogor;

Berhimpon S., 1990.,Studies On Salting And Dry Of Yellowtail., Thesis., Departement of Food Science and Thechnology, School of Applied Bioscience., The University of New South Wales.

Berhimpon S., Dien H.A., Mentang F., 2014., Pengembangan Produk Eksotik Ikan Fufu Non Karsinogenik dengan Memanfaatkan Limbah Industri Perikanan dalam Upaya Meningkatkan Nilai Tambah Ekonomi., Laporan Kemajuan., Penelitian Prioritas Nasional Masterplan Percepatan dan Perluasan Pembangunan Ekonomi Indonesia 2011-2025 (PENPRINAS MP3EI)., Universitas Sam Ratulangi., Manado.

Berhimpon S., Montolalu R.I., Dien H.A., Mentang F., 2016., Scale Up Produksi Ikan Kayu (Katsuo-bushi) Rendah Kandungan Polycyclic Aromatic Hydrocarbon (PAH) Dengan Menggunakan Asap Cair., Laporan Penelitian., PUSNAS., Universitas Sam Ratulangi., Manado.

Dewi, N., M., A., T. 2016. Peptida Antioksidatif Dari Hidrolisat Protein Ikan Kayu. [Skripsi]. Fakultas Perikanan Dan Ilmu Kelautan, Institut Pertanian Bogor.

Esmar Budi. Kajian Pembentukan Karbon Aktif Berbahan Arang Tempurung Kelapa. Seminar Nasional Fisika 2012 Jakarta, 9 Juni 2012 Jurnal Penelitian Sains FMIPA UNSRI.Vol. 14, No. 4 (2011),pp.14406-25

Goula AM, Karapantsios TD, Achilias DS, Adammopoulus KG. 2008. Water sorption isotherms and glass transition temperature of spray dried tomato pulp. Journal of Food Engineering 85(1): 73-83.

Guiilen, M.D., M.J. Manzanos and M.L. Ibargoitia. 2001. Carbohydrate and nitrogenated compounds in liquid smoke flavorings. J Agric Food Chem 49:2395-2403.

Katiandagho, Y., Berhimpon, S., Reo, A., R. 2017. Pengaruh Konsentrasi Asap Cair dan Lama Perendaman Terhadap Mutu Organoleptik Ikan Kayu (Katsuo bushi). Jurnal Media Teknologi Hasil Perikanan, Vol. 5, No. 1, Januari 2017.

Muhtaseb AH, McMinn WAM, Magee TRA. 2004. Water Sorption Isotherms of Starch Powder: Part 1: mathematical description of experimental data. Journal of Food Engineering 61(3): 297-307.

Purnomosari Dyah., 2008., Studi Isoterm Sorpsi Lembab dan Fraksi Air Terikat Pada Tepung Gaplek., Skripsi., Fakultas Pertanian., Universitas Sebelas Maret., Surakarta;

Rahayu S. 1991. Proses Pembuatan Ikan Kayu (Arabushi). Jakarta (ID): Sub Balitkanlut Slipi.

Stolyhwo, A. and Z.E. Sikorski. 2005. Polycyclic aromatic hydrocarbons in smoked fish- a critical review. Food Chem 91: 303-311.

Syarief R., dan Halid H., 1993., Teknologi Penyimpanan Pangan., Penerbit Arcan., Jakarta. 